\title{
Collections and Access Policies of the Digital Material of Ten National Libraries
}

\author{
Alexandros Koulouris, Sarantos Kapidakis \\ Ionian University. Department of Archive and Library Sciences \\ Plateia Eleftherias, Palea Anaktora, Corfu 49100, Greece \\ akoul@ionio.gr,sarantos@ionio.gr
}

\begin{abstract}
There is an ongoing effort from the National Libraries to provide digital content. We encompass the digital collections of ten National Libraries. We examine and analyze the access policies that the ten National Libraries implement, based on the variation of their digital content and the diversification of their access policies. The National Libraries are the following: Library of Congress, British Library, National Library of Australia, National Library of New Zealand, National Library of Canada, National Library of Wales, National Library of Scotland, National Library of Finland, National Library of Greece and National Library of the Netherlands. Our goal is to discover the differences among the implemented access policies of these National Libraries.

In this poster, we explore the collections and the applied access policies, when the digital material is free or restricted or the reproduction requires written permission or fees.

We classify the implemented access policies according to their characteristics. We examine the differences among the implemented access policies and we generalize the solution approaches combining the varying parameters and other relevant emerging ones.

The implemented access policies differ in various aspects. We generalize them into one unified policy, which can implement the specific policies by varying some of its parameters. We study these parameters and explain their most useful alternative values and their semantics. We also foresee new policy parameters, such as charging for access, the delivery method, the permission for reproduction etc., which will be appropriate to more complex policies that will be needed soon.
\end{abstract}

The National Libraries provide free access for onsite and offsite users for the metadata and the non-copyrighted digital material. The variations on their policies mostly refer to the way they handle the copyrighted material. Nearly always, the National Libraries give free access to onsite users for copyrighted material, with few exceptions. The access for offsite users is diversified depending on the collection. However, in most cases, onsite and offsite users have unrestrictedly access to the copyrighted digital

Permission to make digital or hard copies of all or part of this work for personal or classroom use is granted without fee provided that copies are not made or distributed for profit or commercial advantage and that copies bear this notice and the full cit ation on the first page. To copy otherwise, to republish, to post on servers, or to redistribute to lists, requires prior specific permission and/or a fee.

JCDL '03 May 1-2, 2003, Houston, Texas.

Copyright 2000 ACM 1-58113-000-0/00/0000 ...\$5.00. material. The Libraries trust the users and present it to them directly.

Some National Libraries (e.g. National Library of Wales etc.), plan on charging offsite users for copyrighted digital material but they delay the implementation possibly because of the absence of candidate policies. In some cases, written permission is needed for the reproduction of the digital material usually for non-private use, but not for online access. In addition, the Library or any other copyright owner may require a fee for the reproduction. While, the fee given to the copyright owner is copyright fee the fee given to the Library may refer to reproduction or conservation costs (e.g. National Library of New Zealand etc.).

At this moment, most libraries have only digitized or made digitally available, part of their material, the one that is simpler in accessing restrictions, which was simpler to implement and more appropriate to do first. As this process evolves and matures, the libraries want to make more material available and this will force them to handle material that is more complex in terms of copyright and access. The policies that will be applied for accessing this new material will necessarily be more detailed and complex. Thus, the new policy variations must be predicted and standardized.

In the proposed generalized access policy, we classify the users up to four groups that have non-increasing access abilities, as will be defined by the implemented policy. We also classify new charging and delivery parameters for use or reproduction of the non-free digital material. The delivery method could be online when the permission granting is automatic. When written permission is involved, the Library or other permission granter can also provide the digital material online, mainly through ILL.

In conclusion, the digital content is increasing. However, the selection of the access policies is crucial for the acceptance and maintenance of the digital libraries. The success of any conventional or digital library depends on the usage of its material from the users. The usage of the material depends on the selection of the access policy.

To extend this work, it would be interesting to relate the access and the reproduction policies with the way that the library has acquired the material and examine more Libraries. 